\title{
Commentary: You can't have your cake and eat it too: The value paradox in outcomes
}

\author{
Joanna Sesti, MD, and Subroto Paul, MD, MPH
}

\author{
From Department of Thoracic Surgery, RWJBarnabas Health, West Orange, NJ. \\ Disclosures: Authors have nothing to disclose with regard to commercial support. \\ Received for publication Oct 6, 2018; accepted for publication Oct 8, 2018; available ahead of print Nov 17, 2018. \\ Address for reprints: Subroto Paul, MD, MPH, 101 Old Short Hills Rd, Ste 302, West Orange, NJ 07052 (E-mail: \\ Subroto.Paul@rwjbh.org). \\ J Thorac Cardiovasc Surg 2019;157:1646-7 \\ $0022-5223 / \$ 36.00$ \\ Copyright (c) 2018 by The American Association for Thoracic Surgery \\ https://doi.org/10.1016/j.jtcvs.2018.10.028
}

The definition of success varies in life. Cancer operations are no exception. Defining a successful cancer operation is complex because it incorporates not only the concept of cure but also the immediate postoperative recovery period. In other words, surgery would not be thought of as a success if despite performing a good "cancer operation," the patient had a prolonged length of stay marred with complications. Likewise, surgery would not defined as successful if the patient breezed through his/her postoperative course, but had recurrence in a short period of time or was left with residual disease. Fernandez and colleagues have attempted to examine this issue, asking the very important question of, "Is there a correlation between short-term and long-term performance after lung cancer surgery?" ${ }^{1}$ The authors do not find any. You can't have your cake and eat it too.

Their findings imply that a safe, but low-quality lung cancer operation can be performed that is ultimately not beneficial to the patient in the long term. The authors used overall survival, which in an older population can be problematic if patients die of other diseases. One can argue that if the authors examined other oncologic metrics such as disease-free survival, they would have found a correlation. However, the authors were limited by the Society of Thoracic Surgeons (STS) Medicare-linked database they used.

So what does it mean to us surgeons who now live in the "yelpish" era of scores, ratings, and thumbs-up signs? The STS, among other organizations, has attempted to standardize this process by developing a composite score for rating program performance for lobectomies, which includes perioperative morbidity and mortality as outcome measures. ${ }^{2}$ A "star rating" is then assigned on the basis of whether the composite score for the program falls above, within, or below the STS mean. Although at first glance, this appears to be a reasonable way to rate, compare, and assign elite status to certain programs, quality metrics such as "success." resection. ${ }^{4,5}$

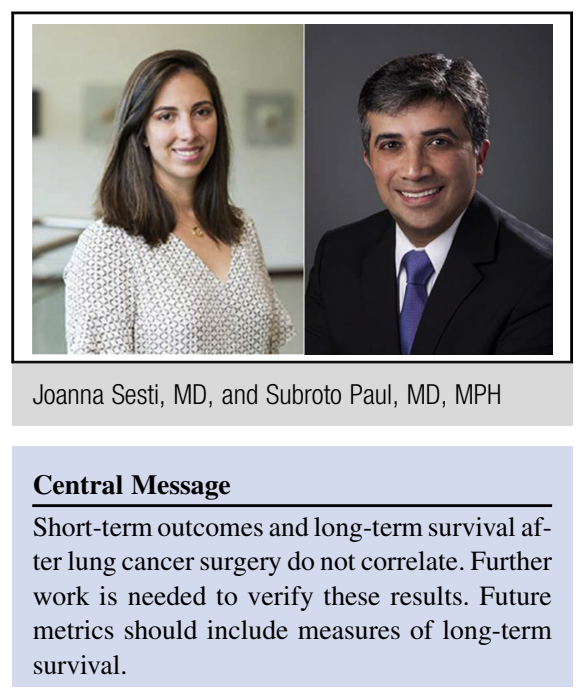

See Article page 1633.

these may not be fully representative of the program's

In many ways, quality metrics favoring short-term outcomes present a value paradox. The paradox of value presented by Adam Smith and others points out the absurdity that water, which is far more useful for basic survival, is worth less than diamonds, which have a higher price in a market economy. ${ }^{3}$ Restricting surgeon performance to markers of short-term outcomes is an incomplete assessment of their oncologic results in lung cancer surgery. We are valuing stars over survival. We must include measures of oncologic quality such as recurrence-free survival, disease-free survival, and overall survival in these assessments. Alternatively, establishing and tracking adherence to preoperative and operative guidelines such as appropriate preoperative staging and risk assessment, completeness of resection, and number of lymph nodes harvested can serve as surrogates for the quality of the oncologic

Surgeons may never be able to align short-term outcomes with long-term outcomes, but we can insist on being evaluated fairly. While ensuring that our patients do well after surgery is a priority, we must also concentrate on providing them good oncologic resections. Regardless of how we personally define "success," this measure should be standardized and adjusted to reflect not only our immediate perioperative results but also how long our patients can 
continue enjoying their lives cancer free, because in the end that is the reason we operate.

\section{References}

1. Fernandez FG, Kosinski AS, Tong BC, Furnary AP, Feng L, Onaitis M, et al. Lack of correlation between short- and long-term performance after lung cancer surgery. J Thorac Cardiovasc Surg. 2019;157:1633-43.e3.

2. Kozower BD, O’Brien SM, Kosinski AS, Magee MJ, Dokholyan R, Jacobs JP, et al. The Society of Thoracic Surgeons composite score for rating program performance for lobectomy for lung cancer. Ann Thorac Surg. 2016;101: 1379-87.

3. Smith A. The Wealth of Nations. Scotland: William Strahan and Thomas Cadell Publishers; 1776.

4. Farjah F, Flum DR, Ramsey SD, Heagerty PJ, Symons RG, Wood DE. Multi-modality mediastinal staging for lung cancer among Medicare beneficiaries. J Thorac Oncol. 2009;4:355-63.

5. Samson P, Crabtree T, Broderick S, Kreisel D, Krupnick AS, Patterson GA, et al Quality measures in clinical stage I non-small cell lung cancer: improved performance is associated with improved survival. Ann Thorac Surg. 2017;103:303-11. 